\title{
Asistensi Pembuatan Website "Mall Pelayanan Publik" Dinas Penanaman Modal Dan Pelayanan Terpadu Satu Pintu Kota Samarinda
}

\author{
Bambang Irawan*1, Muhammad Nizar Hidayat ${ }^{2}$ \\ ${ }^{1}$ Program Studi Magister Administrasi Publik, Universitas Mulawarman \\ 2Program Studi Ilmu Komunikasi, Universitas Lambung Mangkurat \\ *e-mail: bambang.irawan@fisip.unmul.ac.id ${ }^{1}$,nizar.hidayat@ulm.ac.id²
}

\begin{abstract}
The existence of a government website is an initial milestone in the implementation of e-government as an official channel for the dissemination of information related to public services. However, there are still some OPDs that do not have an official website, such as the Samarinda City DPMPTSP which does not yet have a special website related to "Public Service Malls". This is suspected to be due to the lack of competent human resources in managing the government's official website. Based on this, community service this time is intended to provide assistance to the Samarinda City DPMPTSP in terms of making the official website "Public Service Mall" as a form of efforts to strengthen e-government within the Samarinda City Government. This PkM activity is carried out using thematic assistance and training methods
\end{abstract}

Keywords: Assistance, Government Website, DPMPTSP Samarinda City

\begin{abstract}
Abstrak
Keberadaan website pemerintah merupakan tonggak awal dari implementasi e-government sebagai kanal resmi bagi diseminasi informasi terkait dengan pelayanan publik. Meski demikian, masih terdapat beberapa OPD yang belum memiliki website resmi seperti DPMPTSP Kota Samarinda yang belum memiliki website khusus terkait "Mal Pelayanan Publik". Hal ini ditengarai karena kurangnya kualitas sumberdaya manusia yang kompeten dalam pengelolaan website resmi pemerintah. Berdasarkan hal tersebut maka pengabdian kepada masyarakat kali ini ditujukan untuk memberikan asistensi kepada DPMPTSP Kota Samarinda dalam hal pembuatan website resmi "Mal Pelayanan Publik" sebagai bentuk upaya penguatan e-government di lingkup Pemerintah Kota Samarinda. Kegiatan PkM ini dilakukan dengan metode asistensi dan pelatihan tematik. Hasil kegiatan pengabdian ini adalah terbentuknya website "Mal Pelayanan Publik" serta peningkatan keterampilan aparatur di DPMPTSP dalam hal pengelolaan website resmi.
\end{abstract}

Kata kunci: Asistensi, Pembuatan Website, DPMPTSP Kota Samarinda

\section{PENDAHULUAN}

Penetrasi penggunaan Teknologi Informasi atau Information and Communcation Technology (ICT) dalam kehidupan sehari-hari sudah sangat mendalam hingga hampir tak ada satu bidang kehidupan pun yang tidak tersentuh oleh ICT. Hal ini tidak terlepas dari manfaat dari penggunaan ICT dalam mempermudah urusan-urusan manusia. Oleh sebab itu abad ke 21 ini bisa disebut pula dengan abad ICT.

Era ICT juga ditandai dengan keterhubungan (connectedness) yang difasilitasi oleh jaringan internet. Keterhubungan ini membuat semua orang yang memiliki akses internet bisa mendapatkan informasi yang bersifat real-time melalui perangkat mereka. Kondisi yang serba up to date ini kemudian menghadirkan tantangan tersendiri bagi penyediaan informasi khususnya informasi publik yang dibutuhkan oleh masyarakat. Untuk itulah pemerintah dituntut untuk mampu mengikuti arus perkembangan zaman yang dintandai dengan penggunaan ICT dalam sendi-sendi kehidupan masyarakat, termasuk dalam penyelenggaraan urusan pemerintahan.

Dalam kaitannya dengan masyarakat, pemerintah sebagai penyedia layanan publik harus mampu untuk mengkomunikasikan kebijakan publik yang berkaitan langsung dengan kebutuhan masyarakat melalui kanal-kanal resmi yang tersedia. Salah satu kanal resmi yang berfungsi sebagai media penyebaran informasi layanan publik adalah website resmi pemerintah. 
Dalam konteks privat, suatu website menjadi instrumen vital bagi diseminasi atau promosi usaha, hal ini juga berlaku bagi promosi potensi daerah misalnya di bidang pariwisata (Ayuningtyas, Yuliani Indrianingsih, \& Uyuunul Mauidzoh, 2020; Djoni, Yunis, \& Ariwibowo, 2021). Adapun dalam kaitannya dengan pemerintahan, suatu website berperan sebagai gerbang utama interaksi antara masyarakat dan pemerintah dalam jaringan internet. Oleh sebab itu website resmi pemerintah wajib memiliki ciri-ciri yang merefleksikan akuntabilitas, keterbukaan, dan informatif. Keberadaan website resmi pemerintah merupakan bagian dari impelementasi electronic government_ atau biasa dikenal dengan istilah e-government/e-Gov.

E-government sendiri merupakan konsep yang merujuk pada penggunaan ICT dalam melaksanakan pelayanan publik serta bisnis internal pemerintahan yang berkaitan dengan administrasi. Secara umum asumsi yang melekat pada e-government adalah implementasi dari prinsip-prinsip demokrasi seperti keterbukaan, transparansi yang bermuara pada perwujudan tata kelola pemerintahan yang baik (good governance) (United Nations, 2008). Oleh sebab itu maka tidak mengherankan apabila kajian mengenai e-government ini merupakan salah satu kajian yang penting dalam disiplin ilmu Administrasi Publik serta disiplin lain yang serumpun misalnya kajian mengenai konsep dan teori e-government hingga pada komparasi implementasinya pada negara-negara di dunia (Aladwani, 2016; Choi, Park, Rho, \& Zo, 2014; Elkadi, 2013; Guijarro, 2007; Schuppan, 2009; Veeramootoo, Nunkoo, \& Dwivedi, 2018).

Sebagaimana yang telah disinggung sebelumnya, website sebagai salah satu unsur penting dalam e-government juga menjadi titik kajian yang banyak dieksplorasi oleh para penstudi khususnya kajian mengenai evaluasi website (Elling, Lentz, de Jong, \& van den Bergh, 2012; Ismail \& Kuppusamy, 2019; Karkin \& Janssen, 2014; Venkatesh, Hoehle, \& Aljafari, 2014; Verkijika \& De Wet, 2018; Wahid, 2008). Di Indonesia sendiri kajian mengenai evaluasi website pemerintah baik pada level nasional dan daerah juga talah dilakukan oleh peneliti terdahulu yang membahas hal teknis terkait kualitas website pemerintah seperti aksesibilitas, fitur dan lain sebagainya (Effendi \& Susanto, 2019; Irawan \& Hidayat, 2020; Kurniawan, Rakhmawati, Abadi, Zuhri, \& Sugiyanto, 2017; Masyhur, 2014; Yunita \& Aprianto, 2018).

Selain itu terdapat pula kajian yang mengaitkan antara ketersediaan serta kualitas website resmi pemerintah dengan ketercapaian good governance dan demokrasi (Aprilia, Wijaya, \& Suryadi, 2014; Damanik \& Purwaningsih, 2017; Kanter \& Purnama, 2015; Rinaldi \& Yuardani, 2015). Berdasarkan kajian-kajian sebelumnya maka dapat ditarik kesimpulan bahwa keberadaan website resmi pemerintah baik portal utama maupun website masing-masing Organisasi Perangkat Daerah (OPD) sungguh merupakan hal yang vital dalam penyelenggaraan pemerintahan di era ICT ini.

Meski demikian, dalam kenyataannya masih saja terdapat beberapa OPD di Indonesia yang bahkan belum memiliki website resmi khususnya OPD pada pemerintah daerah di luar Pulau Jawa. Salah satu contohnya adalah Dinas Penanaman Modal dan Pelayanan Terpadu Satu Pintu (DPMPTSP) Kota Samarinda. Hal ini dikarenakan kurangnya sumberdaya yang dimiliki oleh DPMPTSP Kota Samarinda baik sumberdaya pendanaan dan sumberdaya manusia yang berkompeten di bidang pembuatan dan manajemen website sebagaimana yang disampaikan oleh Kasi Pengolahan Data DPMPTSP Kota Samarinda (Irawan \& Hidayat, 2021).

Untuk itu penting disinggung disini mengenai konsep digital divide atau kesenjangan digital. Konsep itu merujuk pada akses yang tidak sama terhadap teknologi informasi dan adanya kesenjangan kemampuan yang dibutuhkan untuk menggunakan teknologi informasi. (Pérez-Morote, Pontones-Rosa, \& Núñez-Chicharro, 2020; Suwana \& Lily, 2017). Konsep ini memiliki kaitan erat dengan konsep lain yakni information literacy (literasi informasi) atau digital literacy yang didefinisikan sebagai kapasitas seseorang untuk menggunakan teknologi informasi dan komunikasi sebagai alat untuk mencapai tujuan baik itu tujuan personal maupun professional. (Lee, Lee, \& Lee-Geiller, 2020)

Konsep digital divide menjadi titik permasalahan ketika hal tersebut berimplikasi langsung terhadap keberhasilan program e-government. Permasalahan utama yang dialami oleh 
OPD di Kota Samarinda adalah kurangnya sumberdaya yang dimiliki untuk mengelola website resmi dengan optimal. Pernyataan ini bisa dideduksi dari hasil riset secara nasional yang mengatakan bahwa digital divide di Indonesia masih merupakan masalah besar bahkan di Pulau Jawa yang notabene merupakan pusat pembangunan (Sujarwoto \& Tampubolon, 2016). Artinya ketersediaan sumberdaya manusia yang kompeten untuk mengatur tata kelola website resmi OPD di luar pulau Jawa masih bisa dibilang kurang. Oleh sebab itu maka tidak mengherankan apabila dalam konteks Indonesia secara umum, pembuatan website sebagai sarana diseminasi informasi menjadi salah satu topik yang mendapatkan perhatian akademisi untuk dijadikan tema pengabdian kepada masyarakat (Riki Afriansyah, 2020).

Dengan latar belakang permasalahan tersebut maka Pengabdian Kepada Masyarakat pada kali ini akan diarahkan pada asistensi pembuatan website resmi "Mal Pelayanan Publik" DPMPTSP Kota Samarinda sebagai bentuk penguatan e-government di lingkup Pemerintah Kota Samarinda serta mendukung terciptanya pelayanan publik yang optimal.

\section{METODE}

Sebagaimana yang telah disinggung sebelumnya pada bagian pertama bahwa permasalahan utama yang dimiliki oleh DPMPTSP Kota Samarinda adalah kurangnya sumberdaya baik sumberdaya pendanaan maupun sumberdaya manusia yang kompeten dalam pengelolaan website resmi "Mal Pelayanan Publik". Untuk lebih memahami permasalahan mitra PkM kali ini maka digunakanlah konsep "Digital Divide" atau kesenjangan digital yang terjadi antara Pulau Jawa dan Non-Jawa. Pada kasus ini kesenjangan merujuk pada tidak meratanya distrbusi sumberdaya yang kompeten dan memiliki skill yang dibutuhkan untuk pengelolaan website resmi pemerintah yang berada di lingkup OPD di Pulau Jawa dan non-Jawa sebagaimana yang terjadi di DPMPTSP Kota Samarinda.

Berangkat dari informasi tersebut maka PkM ini berupaya untuk berkontribusi dalam pemecahan permasalahan yang dihadapi oleh DPMPTSP dengan asistensi pembuatan website "Mall Pelayanan Publik" sebagai upaya penguatan e-governement di lingkup Pemerintah Kota Samarinda. Metode pelaksanaan yang digunakan dalam PkM ini terdiri dari beberapa tahapan antara lain:

1. Identifikasi permasalahan

Pada tahap ini dilakukan identifikasi permasalahan dengan menggali informasi langsung dari kantor DPMPTSP Kota Samarinda yang diwakili oleh Kepala Seksi Pengolahan Data, Bapak Syafrilian Apri, S.T. dalam wawancara dengan beliau maka ditemukan permasalahan terkait belum tersedianya website "Mall Pelayanan Publik" yang dimiliki oleh Pemerintah Kota Samarinda, khususnya DPMPTSP.

2. Verifikasi langsung

Tahapan ini dilakukan untuk mengecek ulang dan memastikan bahwa memang informasi yang diberikan oleh narasumber benar adanya. Setelah mencari dan menelusuri laman di internet, ternyata memang tidak tersedia website "Mall Pelayanan Publik" Kota Samarinda

3. Penggalian informasi terkait dengan jenis pelayanan yang akan dimuat dalam website "Mall Pelayanan Publik"

Setelah mengidentifikasi dan memverifikasi permasalahan, maka tahapan selanjutnya adalah penggalian informasi untuk mencri tau jenis pelayanan apa saja yang akan dimuat dalam website "Mall Pelayanan Publik". Tahapan ini dilakukan dengan media daring dan narasumber yakni Kepala Seksi Pengolahan Data DPMPTSP memberikan informasi tentang jenis-jenis pelayanan yang akan dimuat dalam website.

4. Pembuatan website menggunakan domain resmi Pemerintah Kota

Tahapan selanjutnya adalah pembuatan website "Mall Pelayanan Publik" dengan memberdayakan staf DPMPTS Kota Samarinda sebagai operator sekaligus mitra untuk melakukan transfer ilmu terkait dengan pembuatan dan maintenance website resmi. 
5. Evaluasi

Terakhir dilakukan evaluasi terkait dengan asistensi pembuatan dan transfer ilmu terkait pengelolaan website "Mall Pelayanan Publlik" dengan melakukan pengecekan berkala terhadap website tersebut untuk memastikan fitur-fitur utama masih berfungsi.

\section{HASIL DAN PEMBAHASAN}

Pelaksanaan kegiatan PkM dilakukan dengan melalui berbagai tahapan sebagaimana yang telah dijabarkan sebelumnya. tahapan pertama adalah tahapan identifikasi permasalahan dimana informasi awal terkait dengan masalah di DPMPTS Kota Samarinda dipaparkan oleh Kepala Seksi Pengolahan Data, Syafrilian Apri, S.T. tahapan berikutnya, tim PkM melakukan verifikasi dengan menelusuri internet dengan kata kunci "Mall Pelayanan Publik Kota Samarinda" dan tidak menemukan website yang dimaksud. Setelah itu tim PkM dan Kepala Seksi Pengolahan Data kembali bertemu untuk menentukan jenis-jenis pelayanan apa saja yang akan ditampilkan pada website yang akan dibuat.

Pada tahapan ini dibuatlah semacam "dummy" atau sketsa dari isi bangunan website yang akan dibuat. Rancangan atau sketsa bangunan website ini dibuat dalam bentuk Power Point (PPT) terlebih dahulu agar memudahkan tim PkM maupun pihak DPMPTSP untuk merubah isi konten website. Hal ini juga berfungsi sebagai visualisasi rancangan website yang menjadi bahan diskusi dalam pembuatan website ini.

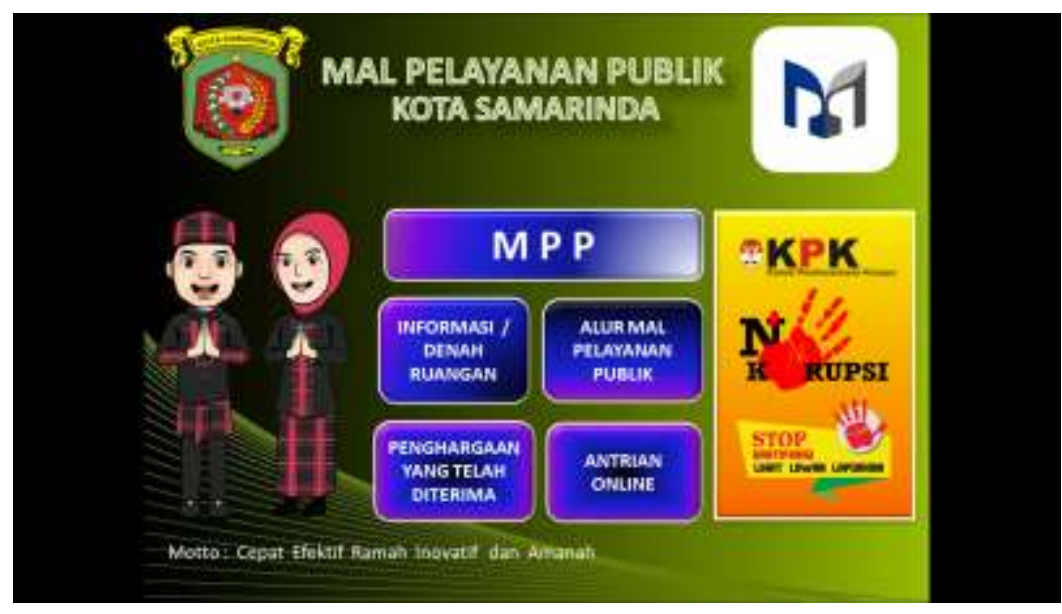

Gambar 1. Tampilan PPT “Dummy” Website

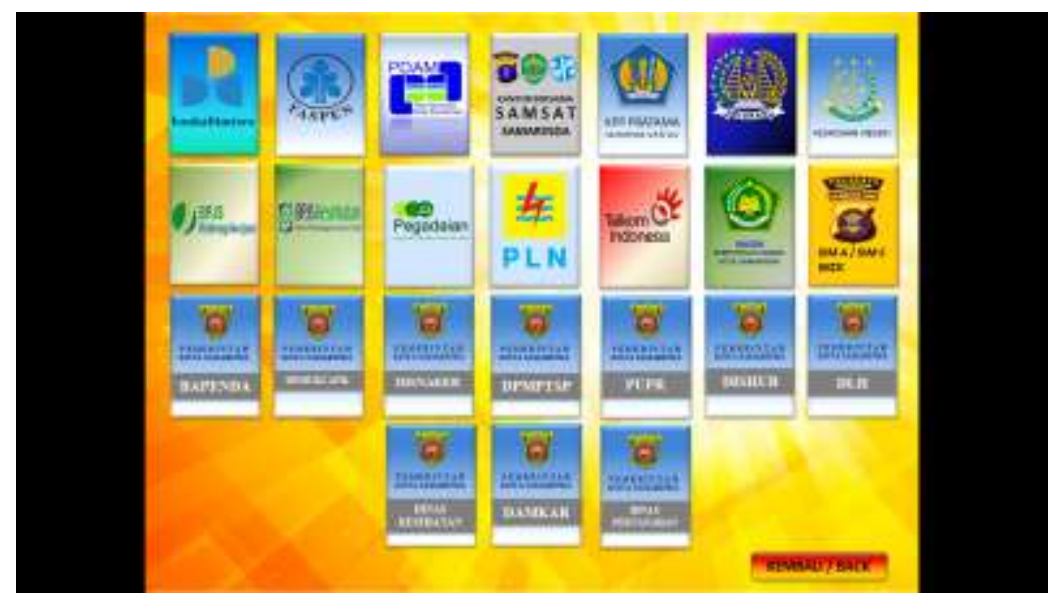

Gambar 2. Tampilan Isi Menu Rancangan Website 
Pada tahapan ini Power Point rancangan website ini berisi bangunan utama website yang berisi jenis-jenis pelayanan, informasi denah/ruangan, alur mal pelayanan publik, penghargaan yang telah diterima oleh DPMPTSP Kota Samarinda, dan fitur antrian online bagi para pemohon perizinan. Selain itu juga disepakati untuk ditambahkan tautan-tautan lain seperti link ke website KPK dan slogan-slogan anti korupsi dan anti gratifikasi. Satu per satu fitur yang ada pada "dummy" website itu ditelaah dan didiskusikan bersama oleh tim PkM dan Kasi Pengolah Data DPMPTSP Kota Samarinda selama beberapa waktu antara Juli sampai Agustus 2021. Setelah dirasa sudah memenuhi kriteria website resmi dan informasi yang disampaikan juga telah diuraikan dengan jelas, maka proses pembuatan website pun segera dilaksanakan. DPMPTSP menunjuk salah satu staff mereka sebagai operator website "Mall Pelayanan Publik" sekaligus sebagai mitra yang akan diberikan asistensi serta transfer ilmu pengelolaan website resmi.

Namun sebagai permulaan, tim PkM telah terlebih dahulu membuatkan kerangka dasar website tersebut dengan bantuan dari anggota tim yang bekerja di Dinas Komunikasi dan Informatika Kota Samarinda.

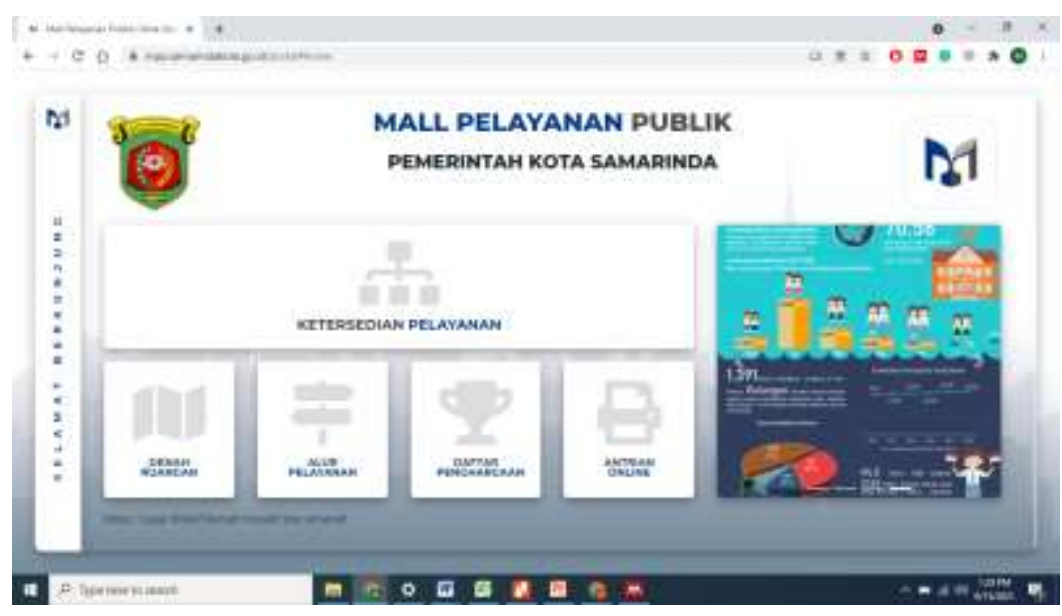

Gambar 3. Tampilan Website MPP DPMPSTSP Kota Samarinda

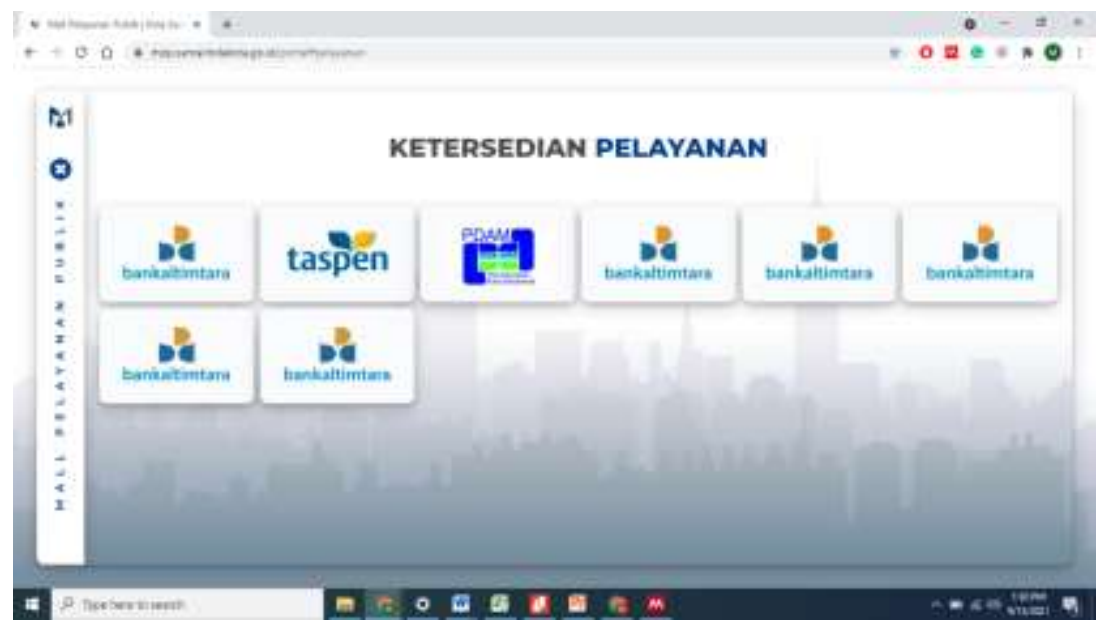

Gambar 4. Fitur Pelayanan Website MPP DPMPSTSP Kota Samarinda 


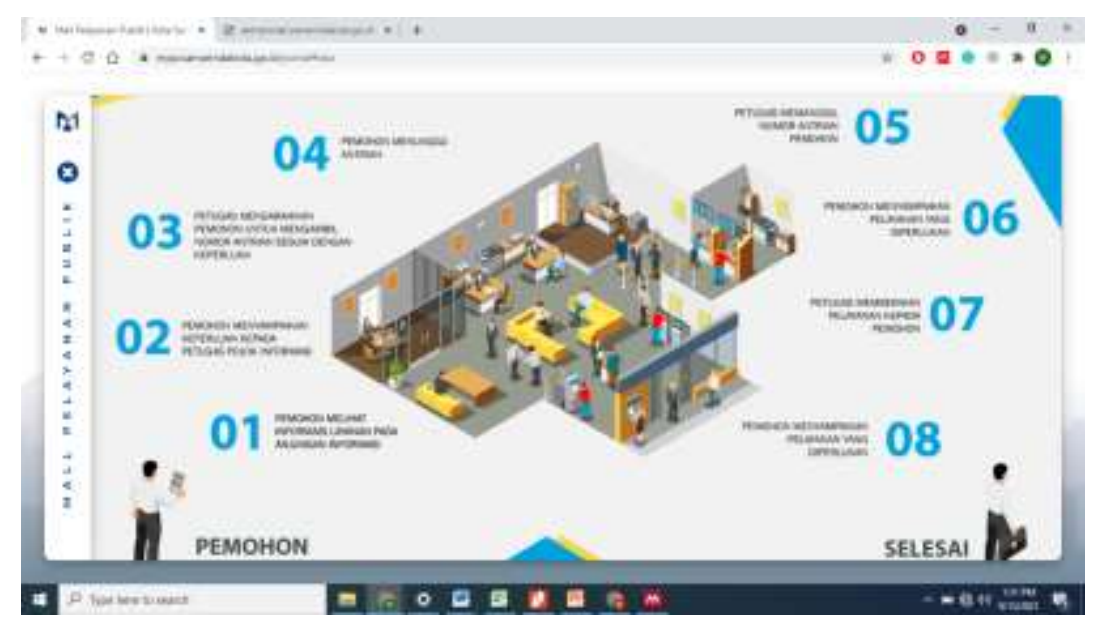

Gambar 5. AlurPelayanan Website MPP DPMPSTSP Kota Samarinda

Setelah menyediakan framework awal dari website MPP, tim PkM melakukan asistensi atau pendampingan kepada operator website untuk melakukan pengisian konten secara mandiri serta melakukan update atau pembaharuan berkala terkait dengan informasi berita atau pengumuman tententu. Operator website diberikan username dan password untuk mengakses e-panel website MPP tersebut, dan diberikan pemahaman dan pengetahuan tentang bagaimana mengoperasikan fitur-fitur yang tersedia dalam e-panel tersebut.

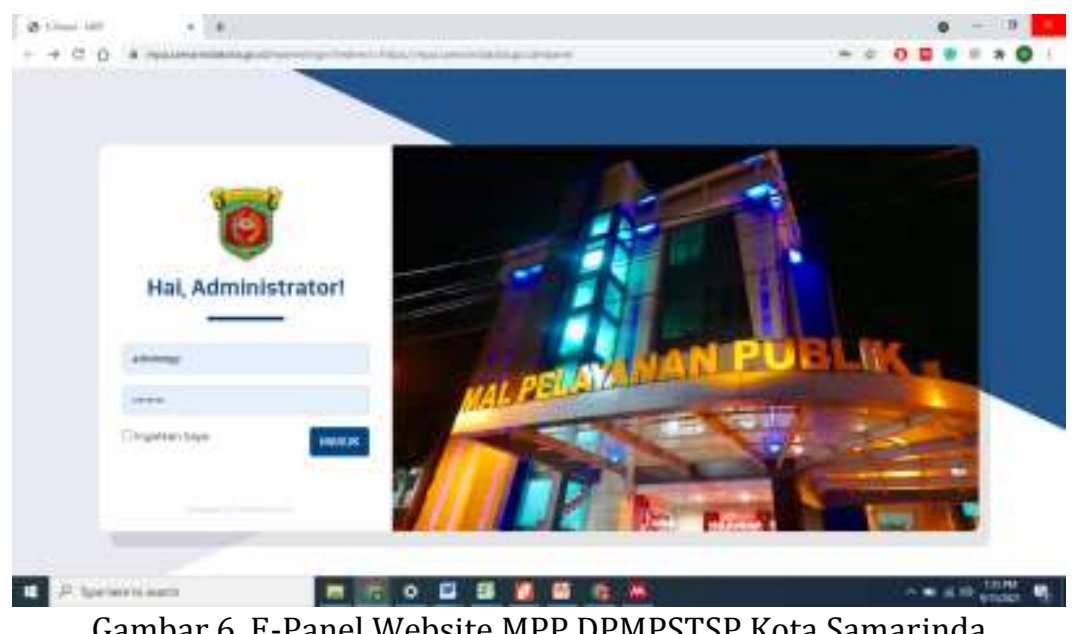

Gambar 6. E-Panel Website MPP DPMPSTSP Kota Samarinda

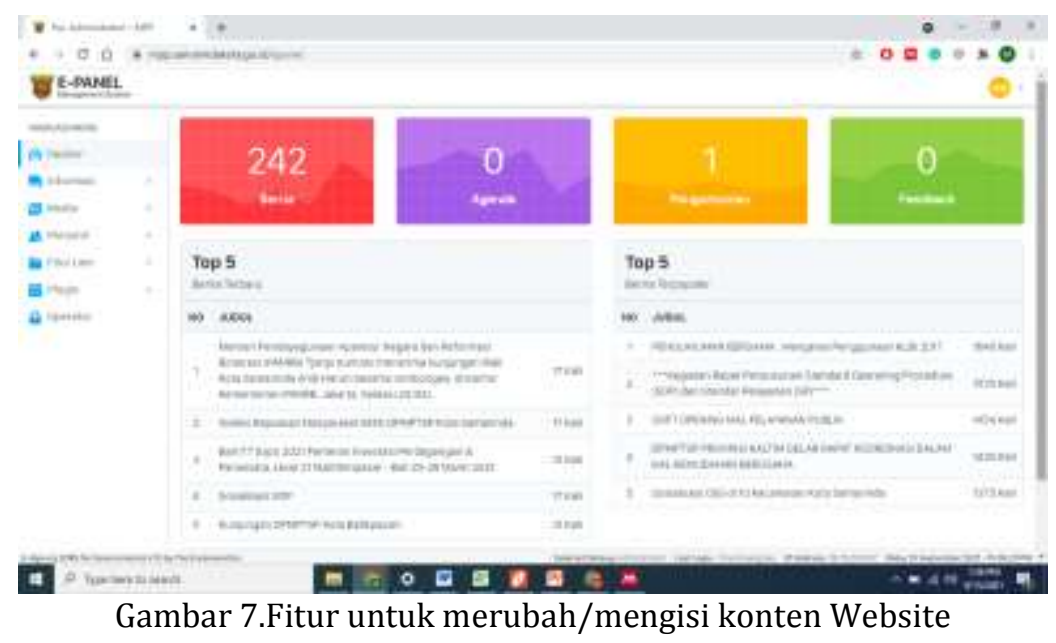


Untuk melakukan evaluasi terhadap asistensi dan transfer ilmu yang sudah diberikan , maka tim PkM secara berkala mengunjungi website Mall Pelayanan Publik Kota Samarinda untuk meliat apakah ada terjadi perubahan ataupun permasalahan aksesibilitas yang terjadi. Berdasarkan evaluasi yang dilakukan, asistensi dan transfer ilmu yang dilakukan telah berhasil meningkatkan kemampuan operator website di DPMPTSP Kota Samarinda.

\section{KESIMPULAN}

Di era digital ini, keberadaan dan kehadiran pemerintah bisa diidentifikasi dari adanya website resmi sebagai kanal pelayanan. Meski demikian, terlepas dari kemajuan teknologi yang ada ternyata masih ada beberapa pemerintah daerah yang belum mampu memaksimalkan egovernment. Salah satunya adalah Pemerintah Kota Samarinda, khusunya Dinas Penanaman Modal dan Pelayanan Terpadu Satu Pintu (DPMPTSP) yang ternyata masih belum memiliki website khusus terkait "Mall Pelayanan Publik" (MPP).

Untuk itulah PkM ini berupaya untuk melakukan asistensi pembuatan dan pengelolaan website MPP yang bertujuan untuk memberikan transfer ilmu serta peningkatan kapabilitas operator website di kantor DPMPTSP. Berdasarkan hasil PkM, diketahui bahwa program asistensi dan transfer ilmu terkait pembuatan dan pengelolaan website resmi pemerintah berjalan dengan lancar yang bisa diverifikasi melalui evaluasi berkala yang dilakukan oleh tim PkM.

\section{UCAPAN TERIMA KASIH}

Ucapan terima kasih kami tujukan kepada Progsam Magister Administrasi Publik Fakultas Ilmu Sosial dan Ilmu Politik Universitas Mulawarman yang telah berkenan untuk memberikan pendanaan bagi PkM kali ini.

\section{DAFTAR PUSTAKA}

Aladwani, A. M. (2016). Corruption as a source of e-Government projects failure in developing countries: A theoretical exposition. International Journal of Information Management, 36(1), 105-112. https://doi.org/10.1016/j.ijinfomgt.2015.10.005

Aprilia, S., Wijaya, A., \& Suryadi, S. (2014). Efektivitas Website Sebagai Media E-Government dalam Meningkatkan Pelayanan Elektronik Pemerintah Daerah (Studi Pada Website Pemerintah Daerah Kabupaten Jombang). Wacana, Jurnal Sosial Dan Humaniora, 17(3), 126135. https://doi.org/10.21776/ub.wacana.2014.017.03.3

Ayuningtyas, A., Yuliani Indrianingsih, \& Uyuunul Mauidzoh. (2020). Pengenalan, Optimalisasi Optimalisasi Pengenalan Produk Unggulan Desa Melalui Pelatihan Website Promosi Kecamatan Patuk Gunungkidul. Dinamisia: Jurnal Pengabdian Kepada Masyarakat, 4(3), 490-495. https://doi.org/10.31849/dinamisia.v4i3.3782

Choi, H., Park, M. J., Rho, J. J., \& Zo, H. (2014). Rethinking the assessment of e-government implementation in developing countries from the perspective of the design-reality gap: Applications in the Indonesian e-procurement system. Telecommunications Policy, 40(7), 644-660. https://doi.org/10.1016/j.telpol.2016.03.002

Damanik, M. P., \& Purwaningsih, E. H. (2017). E-GOVERNMENT DAN APLIKASINYA DI LINGKUNGAN PEMERINTAH DAERAH (Studi Kasus Kualitas Informasi Website Kabupaten Bengkalis Propinsi Riau). Jurnal Studi Komunikasi Dan Media, 21(2), 151-164.

Djoni, Yunis, R., \& Ariwibowo, S. (2021). Penguatan Promosi Melalui Media Website pada Hotel Alvina Pematangsiantar. Dinamisia : Jurnal Pengabdian Kepada Masyarakat, 5(3), 772-782. https://doi.org/10.31849/dinamisia.v5i3.6287

Effendi, P. M., \& Susanto, T. D. (2019). Test of citizens' physical and cognitive on Indonesian egovernment website design. Procedia Computer Science, 161, 333-340. 
https://doi.org/10.1016/j.procs.2019.11.131

Elkadi, H. (2013). Success and failure factors for e-government projects: A case from Egypt. Egyptian Informatics Journal, 14(2), 165-173. https://doi.org/10.1016/j.eij.2013.06.002

Elling, S., Lentz, L., de Jong, M., \& van den Bergh, H. (2012). Measuring the quality of governmental websites in a controlled versus an online setting with the "Website Evaluation Questionnaire." Government Information Quarterly, 29(3), 383-393. https://doi.org/10.1016/j.giq.2011.11.004

Guijarro, L. (2007). Interoperability frameworks and enterprise architectures in e-government initiatives in Europe and the United States. Government Information Quarterly, 24(1), 89101. https://doi.org/10.1016/j.giq.2006.05.003

Irawan, B., \& Hidayat, M. N. (2020). Evaluasi aksesibilitas website covid19.kaltimprov.go.id menggunakan sortsite 5.3.5. Jurnal Paradigma, 9(2), 119-130. https://doi.org/http://dx.doi.org/10.52239/jp.v9i2

Irawan, B., \& Hidayat, M. N. (2021). Wawancara Dengan Syafrilian Ardi, ST, Kasi Pengolahan Data DPMPTSP Kota Samarinda (25 Maret 2021). Samarinda.

Ismail, A., \& Kuppusamy, K. S. (2019). Web accessibility investigation and identification of major issues of higher education websites with statistical measures: A case study of college websites. Journal of King Saud University - Computer and Information Sciences, (xxxx). https://doi.org/10.1016/j.jksuci.2019.03.011

Kanter, C., \& Purnama, A. (2015). Peran Website Pemerintah Kota Manado Dalam Mendukung Terwujudnya Good Governance. Jurnal Penelitian Komunikasi Dan Opini Publik, 19(3), 123272.

Karkin, N., \& Janssen, M. (2014). Evaluating websites from a public value perspective: A review of Turkish local government websites. International Journal of Information Management, 34(3), 351-363. https://doi.org/10.1016/j.ijinfomgt.2013.11.004

Kurniawan, F., Rakhmawati, N. A., Abadi, A. N., Zuhri, M., \& Sugiyanto, W. T. (2017). Indonesia local government information completeness on the web. Procedia Computer Science, 124, 2128. https://doi.org/10.1016/j.procs.2017.12.125

Lee, T., Lee, B. K., \& Lee-Geiller, S. (2020). The effects of information literacy on trust in government websites: Evidence from an online experiment. International Journal of Information Management, 52(August 2019). https://doi.org/10.1016/j.ijinfomgt.2020.102098

Masyhur, F. (2014). Kinerja Website Resmi Pemerintah Provinsi di Indonesia. Pekommas, 17(1), 9-14. Retrieved from http://download.portalgaruda.org/article.php?article=266814\&val=6557\&title=Kinerja Website Resmi Pemerintah Provinsi di Indonesia

Pérez-Morote, R., Pontones-Rosa, C., \& Núñez-Chicharro, M. (2020). The effects of e-government evaluation, trust and the digital divide in the levels of e-government use in European countries. Technological Forecasting and Social Change, 154(January), 119973. https://doi.org/10.1016/j.techfore.2020.119973

Riki Afriansyah. (2020). Pembuatan Portal Website Sekolah Sma Negeri 1 Sungailiat Sebagai Media Informasi. Dinamisia: Jurnal Pengabdian Kepada Masyarakat, 5(1), 154-160. https://doi.org/10.31849/dinamisia.v5i1.4413

Rinaldi, H., \& Yuardani, A. M. (2015). Analisis Peluang Transformasi "E-Government" menjadi "EDemocracy"melalui Website Resmi Pemerintah Daerah. MIMBAR, Jurnal Sosial Dan Pembangunan, 31(1), 103. https://doi.org/10.29313/mimbar.v31i1.1201

Schuppan, T. (2009). E-Government in developing countries: Experiences from sub-Saharan Africa. Government Information Quarterly, 26(1), 118-127. https://doi.org/10.1016/j.giq.2008.01.006

Sujarwoto, S., \& Tampubolon, G. (2016). Spatial inequality and the Internet divide in Indonesia 2010-2012. Telecommunications
https://doi.org/10.1016/j.telpol.2015.08.008

Suwana, F., \& Lily. (2017). Empowering Indonesian women through building digital media literacy. Kasetsart Journal of Social Sciences, 38(3), 212-217. 
https://doi.org/10.1016/j.kjss.2016.10.004

United Nations. (2008). United Nations e-Government Survey 2008: From e-Government to Connected Governance. New York.

Veeramootoo, N., Nunkoo, R., \& Dwivedi, Y. K. (2018). What determines success of an egovernment service? Validation of an integrative model of e-filing continuance usage. Government Information Quarterly, 35(2), 161-174. https://doi.org/10.1016/j.giq.2018.03.004

Venkatesh, V., Hoehle, H., \& Aljafari, R. (2014). A usability evaluation of the Obamacare website. Government Information Quarterly, 31(4), 669-680. https://doi.org/10.1016/j.giq.2014.07.003

Verkijika, S. F., \& De Wet, L. (2018). A usability assessment of e-government websites in SubSaharan Africa. International Journal of Information Management, 39(September 2017), 20 29. https://doi.org/10.1016/j.ijinfomgt.2017.11.003

Wahid, F. (2008). Evaluating Focus and Quality of Indonesian E-Government Websites. Seminar Nasional Aplikasi Teknologi Informasi, 2008(Snati), 39-43.

Yunita, N. P., \& Aprianto, R. D. (2018). Kondisi Terkini Perkembangan Pelaksanaan EGovernment di Indonesia: Analisis Website. Seminar Nasional Teknologi Informasi Dan Komunikasi, 2018(Sentika), 23-24. Retrieved from https://fti.uajy.ac.id/sentika/publikasi/makalah/2018/40.pdf 